\title{
Dynamics of humus forms and soil characteristics along a forest altitudinal gradient in Hyrcanian forest
}

\author{
Mohammad Bayranvand ${ }^{(1)}$, \\ Moslem Akbarinia ${ }^{(1)}$, \\ Gholamreza Salehi Jouzani (2), \\ Javad Gharechahi ${ }^{(3)}$, \\ Giorgio Alberti ${ }^{(4)}$
}

\begin{abstract}
Humus forms are good indicators of environmental conditions and thus important in forest ecological processes. Altitudinal gradients are considered as natural laboratory for evaluating soil ecological processes and humus form distribution. The objective of this study was to evaluate the macromorphology of humus forms along an altitudinal gradient (0-2000 $\mathrm{m}$ a.s.l.) covered with plain forest, mixed and pure forests and forest-grassland ecotone, in Alborz Mountains in northern Iran. In total, 225 humus profiles were evaluated. Forest stand variables including tree density, basal area, crown density, and height, forest floor and soil physico-chemical properties along with biological features were measured. We found that altitudinal gradients influence both humus forms distribution and soil properties but with different mechanisms. While soil properties (i.e., temperature, $\mathrm{pH}, \mathrm{CaCO}_{3}$, soil $\mathrm{N}$ content, soil $\mathrm{C} / \mathrm{N}$ and microbial biomass $\mathrm{N}$ ) were significantly correlated with altitude, the forest floor properties were more influenced by tree species composition. Particularly, the abundance of Mull was decreased in plain mixed forests compared to mountain pure forests, whereas the frequency of Amphi was increased. Moreover, Oligomull and Leptoamphi were abundant in mixed beech forests, while Eumacroamphi, Eumesoamphi and Pachyamphi were only observed in pure beech forests. Such a distribution influenced soil fertility where higher values of nitrogen $(\mathrm{N})$, microbial biomass nitrogen $(\mathrm{MBN})$ and $\mathrm{pH}$ were observed at lower altitudes under mixed forests compared to pure forests at higher altitudes.
\end{abstract}

Keywords: Altitude Gradient, Plant-humus-soil Relationships, Humus Systems, Soil Microbial Biomass

soil fertility (Salmon 2018).

The current classification systems enabled to distinguish five humus systems and sixteen humus forms in terrestrial ecosystems (Jabiol et al. 2013, Zanella et al. 2018). Humus forms can be directly identified in field without the need for expensive laboratory tools (Zanella et al. 2018).

According to Zanella et al. (2011), temperature, precipitation and vegetation composition are the three most important factors affecting biological degradation of organic residues and contributing in the formation

(1) Faculty of Natural Resources and Marine Sciences, Tarbiat Modares University, 4641776489, Noor, Mazandaran (Iran); (2) Microbial Biotechnology Department, Agricultural Biotechnology Research Institute of Iran (ABRII), Agricultural Research, Education and Extension Organization (AREEO), Fahmideh Blvd., P.O. Box:31535-1897, Karaj (Iran); (3) Human Genetics Research Center, Baqiyatallah University of Medical Sciences, Tehran (Iran); (4) Department of Agri-food, Environmental and Animal Sciences, University of Udine, v. delle Scienze 206, 33100 Udine (Italy)

@ Gholamreza Salehi Jouzani (gsalehi@abrii.ac.ir)

Received: Apr 09, 2020 - Accepted: Nov 02, 2020

Citation: Bayranvand M, Akbarinia M, Salehi Jouzani G, Gharechahi J, Alberti G (2021). Dynamics of humus forms and soil characteristics along a forest altitudinal gradient in Hyrcanian forest. iForest 14: 26-33. - doi: 10.3832/ifor3444-013 [online 2021-01-10]

of different humus forms. On the other hand, altitude through changes in temperature and precipitation, affects the distribution of forest species, forest floor quality and quantity (Bayranvand et al. 2017b), soil characteristics (Ponge et al. 2011), microorganism types and activities (Zhang et al. 2013, Xu et al. 2015), thus contributing in humus forms (Ascher et al. 2012, Salmon 2018). Altitudinal gradients are considered as natural laboratories for evaluating soil ecological processes (Labaz et al. 2014, Bojko \& Kabala 2017). Understanding the complex interactions between soil and plant communities along altitude gradients can be used for the prediction of soil microbial activity and forest floor decomposition (Bojko \& Kabala 2017, Xu et al. 2015).

The natural broadleaf forests in northern Iran are similar to those in central Europe, northern Turkey and the Caucasus. In these forest ecosystems, composition of tree species changes with elevation (Bayranvand et al. 2017a). Due to their unique topographical conditions compared to the oldest forest in Asia, Alborz mountains offers the potential to assess changes in forest types and humus forms with altitude (Naqinezhad et al. 2013). So far, few studies investigated the pattern of humus forms, forest floor features and soil microbial biomass along altitudinal gradients (Bayranvand et al. 2017b, Waez-Mousavi 
2018).

In this study, we described humus morphology, forest floor, soil quality, microbial biomass carbon (MBC) and nitrogen (MBN) in five different forest types along an altitudinal gradient from 0 to $2000 \mathrm{~m}$ a.s.l. (i.e., plain forest, low, medium and high mountainous mixed and pure forests, and forestgrassland ecotone). We hypothesized that: (1) increased beech species abundance and decreased soil temperature along altitudinal gradient strongly affect the pattern of humus forms and organic layer thickness; (2) forest floor and soil characteristics change with altitude and soil fertility; (3) specific soil chemical and biological features correlate with humus forms and vegetation characteristics.

\section{Material and methods}

\section{Site description}

With an area of about 14,000 hectares, the Vaz catchment forests are located in the northern Alborz mountain, beside the Caspian Sea, in northern Iran $\left(36^{\circ} 16^{\prime} \mathrm{N}, 52^{\circ}\right.$ $48^{\prime} \mathrm{E}-$ Fig. S1 in Supplementary material). The study area was located along an altitude gradient 0-2000 $\mathrm{m}$ a.s.l. Forest vegetation in this area largely depends on altitude and therefore five different forest types could be distinguished (Khaleghi et al. 1997): (1) plain mixed forests (PMF - o m a.s.I.): Ironwood (Parrotia persica C.A. Meyer), Oak (Quercus castaneifolia C. A. M.) and Hornbeam (Carpinus betulus L.); (2) low mountainous mixed forests (LMMF -500 $\mathrm{m}$ a.s.l.): Beech (Fagus orientalis Lipsky), Ash (Fraxinus excelsior L.), Parrotia persica C. A. Meyer, Acer (Acer velutinum Boiss) and Carpinus betulus; (3) middle mountainous mixed forests (MMMF - $1000 \mathrm{~m}$ a.s.l.): Beech (Fagus orientalis Lipsky), Ash (Fraxinus excelsior L.), Parrotia persica C. A. Meyer, Acer (Acer velutinum Boiss) and Carpinus betulus; (4) high mountainous pure forests (HMPF - $1500 \mathrm{~m}$ a.s.l.): Fagus orientalis Lipsky; (6) forest-grassland ecotone (F-GE - $2000 \mathrm{~m}$ a.s.l.): Hawthorn (Crataegus sp.), Pear (Pyrus communis L.), Apple (Malus communis L.), Barberry (Berberis crataegina), Maple-AC (Acer campestre L.).

The mean annual temperature at PMF, LMMF, MMMF, HMPF and F-GE are 19.2, $16.3,14,11.6$, and $8{ }^{\circ} \mathrm{C}$, respectively. For every $1000 \mathrm{~m}$ increase in altitude, an average $3-5{ }^{\circ} \mathrm{C}$ decrease in temperature has been recorded. The mean annual precipitations are $898,843,805,746$ and $844 \mathrm{~mm}$ in PMF, LMMF, MMMF, HMPF and F-GE, respectively (Karger et al. 2017). About 35-45\% of the rainfall occurs in autumn (from September to November), $18-35 \%$ in winter (December to February), and the rest (10$20 \%$ ) in summer (June to August; Noushahr city meteorological station, 1977-2010 - Fig. S2 in Supplementary material). Based on World Reference Basis (WRB) and USDA Soil Taxonomies, plain forest soils were classified as Cambisols (Inceptisol), low and medium altitudes as Luvisols (Alfisols), and higher altitudes as Phaeozems (Mollisols) and Cambisols, developed on dolomite limestones belonging to the upper
Jurassic and lower Cretaceous period (Khaleghi et al. 1997, IUSS Working Group 2015).

Experimental design, tree investigation, humus identification, forest floor and soil sampling

At each altitude (0, 500, 1000, 1500 and $2000 \mathrm{~m}$ a.s.l.), three 1-ha plots with at least $1500 \mathrm{~m}$ distance were delimited. Elevation at each plot was recorded using a Garmin ${ }^{T M}$ model GPSMAP ${ }^{\circledR} 60 \mathrm{Cx}$ (Olathe, KS, USA). Aspect values were assigned using angles from 0 to $360^{\circ}$ given by a pocket compass. In each plot, three random subplots (400 $\mathrm{m}^{2}$ ) were chosen for sampling. All living trees were counted at each subplot. The diameter at breast-height (DBH, $1.3 \mathrm{~m}$ ) and total height $(>1.3 \mathrm{~m}$ ) of all living trees were measured with a diameter tape and Impulse $^{\circledast} 200$ Laser Hypsometer (Laser Technology Inc., Centennial, CO, USA), respectively (Tab. 1)

The experiment was conducted during April 2018. Humus profiles (Organic: OL, $\mathrm{OF}, \mathrm{OH}$; and organic-mineral: $\mathrm{AH}$ ) and diagnostic horizons were described and sampled at the corners and at the center of each sub-plot using a metal frame $(30 \times 30$ $\mathrm{cm})$. The morphological characteristics of each humus profile were described according to Zanella et al. (2018). The basilar elements of the adopted humus classifications are reported in Tab. S1 (Supplementary material). Humus layer thickness (HLT) was also measured with a tape from the forest floor surface to the top of the mineral soil. The earthworm ecological groups (i.e., Epi-

Tab. 1 - Mean \pm standard error $(n=9)$ and Pearson's correlation coefficients $\left(R_{c o r}\right)$ of vegetation characteristics along the altitudinal gradient in Hyrcanian forests. (PMF): plain mixed forests; (LMMF): low mountainous mixed forests; (MMMF): middle mountainous mixed forests; (HMPF): high mountainous pure forests; (F-GE): forest-grassland ecotone. Different letters indicate significant differences $(p<0.05)$ among altitude levels after Tukey HSD test. $(*): p<0.05 ;(* *): p<0.01$.

\begin{tabular}{|c|c|c|c|c|c|c|c|c|}
\hline \multirow{2}{*}{ Variables } & \multicolumn{5}{|c|}{ Altitudinal gradient (m a.s.l.) } & \multicolumn{2}{|c|}{ ANOVA results } & \multirow{2}{*}{$\mathbf{R}_{\text {cor }}$} \\
\hline & 0 & 500 & 1000 & 1500 & 2000 & F test & P-value & \\
\hline Forest type & PMF & LMMF & MMMF & HMPF & F-GE & - & - & - \\
\hline Tree density $\left(\mathrm{n} \mathrm{ha}{ }^{-1}\right)$ & $263.8 \pm 15.6^{\mathrm{cd}}$ & $405.6 \pm 57.4^{\mathrm{bc}}$ & $175.0 \pm 16.1^{\mathrm{d}}$ & $586.1 \pm 64.5^{\mathrm{a}}$ & $558.3 \pm 34.8^{\mathrm{ab}}$ & 17.53 & $<0.001$ & $0.54^{* *}$ \\
\hline Tree basal area $\left(\mathrm{m}^{2} \mathrm{ha}^{-1}\right)$ & $31.5 \pm 6.1 \mathrm{abc}$ & $39.3 \pm 10.9^{a b}$ & $60.6 \pm 10.8^{a}$ & $17.5 \pm 2.8^{\mathrm{bc}}$ & $2.9 \pm 0.3^{c}$ & 8.52 & $<0.001$ & $-0.39^{* *}$ \\
\hline Tree crown density (\%) & $82.3 \pm 1.9^{\mathrm{a}}$ & $76.9 \pm 2.6^{\mathrm{ab}}$ & $76.8 \pm 2.9^{\mathrm{ab}}$ & $68.4 \pm 1.1^{b}$ & $44.7 \pm 2.2^{c}$ & 44.71 & $<0.001$ & $-0.79^{* *}$ \\
\hline Mean tree height $(\mathrm{m})$ & $16.7 \pm 0.5^{c}$ & $21.1 \pm 0.9^{b}$ & $26.6 \pm 0.5^{\mathrm{a}}$ & $17.3 \pm 0.44^{c}$ & $5.2 \pm 0.3^{d}$ & 187.68 & $<0.001$ & $-0.52^{* *}$ \\
\hline Beech density ( $\mathrm{n} \mathrm{ha}^{-1}$ ) & - & $230.5 \pm 49.6^{b}$ & $91.7 \pm 13.8^{\mathrm{bc}}$ & $586.1 \pm 64.6^{a}$ & - & 43.99 & $<0.001$ & - \\
\hline Oak density (n ha ${ }^{-1}$ ) & $33.3 \pm 9.32$ & - & - & - & - & - & - & - \\
\hline Hornbeam density $\left(\mathrm{n} \mathrm{ha}^{-1}\right)$ & $22.2 \pm 10.6$ & - & $36.1 \pm 8.5$ & - & - & - & - & - \\
\hline Maple-AV density $\left(\mathrm{n} \mathrm{ha}^{-1}\right)$ & - & $2.8 \pm 2.8$ & $33.3 \pm 11.1$ & - & - & - & - & - \\
\hline Ash density ( $\mathrm{n} \mathrm{ha}^{-1}$ ) & - & $97.2 \pm 36.4$ & - & - & - & - & - & - \\
\hline Alder density $\left(\mathrm{n} \mathrm{ha}^{-1}\right)$ & $2.8 \pm 2.8$ & - & - & - & - & - & - & - \\
\hline Iron wood density $\left(\mathrm{n} \mathrm{ha}^{-1}\right)$ & $194.4 \pm 22.4^{\mathrm{a}}$ & $75.0 \pm 17.7^{b}$ & $8.3 \pm 2.3^{c}$ & - & - & 39.80 & $<0.001$ & - \\
\hline Populus density ( $\mathrm{n} \mathrm{ha}^{-1}$ ) & $11.1 \pm 4.39$ & - & - & - & - & - & - & - \\
\hline Hawthorn density $\left(\mathrm{n} \mathrm{ha}^{-1}\right)$ & - & - & - & - & $344.4 \pm 33.1$ & - & - & - \\
\hline Pear density $\left(\mathrm{n} \mathrm{ha}^{-1}\right)$ & - & - & - & - & $94.4 \pm 33.1$ & - & - & - \\
\hline Apple density ( $\mathrm{n} \mathrm{ha}^{-1}$ ) & - & - & - & - & $63.9 \pm 22.9$ & - & - & - \\
\hline Barberry density $\left(\mathrm{n} \mathrm{ha}^{-1}\right)$ & - & - & - & - & $27.8 \pm 11.4$ & - & - & - \\
\hline Maple-AC density $\left(\mathrm{n} \mathrm{ha}^{-1}\right)$ & - & - & - & - & $27.8 \pm 10.6$ & - & - & - \\
\hline Soil texture & clay & clay / clay loam & clay / clay loam & clay / clay loam & clay loam & - & - & - \\
\hline
\end{tabular}


geic, Anecic and Endogeic) were also identified (Bohlen 2002). Forest floor samples including $\mathrm{OL}$ and $\mathrm{OF}$ layers were finely mixed before sampling. To remove soil, the forest floor samples were soaked gently in tap water for a few seconds (this is not recommended for samples dominated by $\mathrm{OH}$ layers) and then dried at $70{ }^{\circ} \mathrm{C}$ for $48 \mathrm{~h}$. Dried forest floor samples were finely grounded/homogenized with an electric mixer and analyzed.

Top mineral soil samples (depth $0-10 \mathrm{~cm}$ ) were collected after removal of the organic layers. Using a standard soil auger (5 $\mathrm{cm}$ inner diameter). Soil temperature (ST) was measured at a depth $0-10 \mathrm{~cm}$ with a portable temperature probe (model TA288 ). Since no rainfall occurred during the sampling time, temperature was quite constant during the day.

To determine microbial biomass, the soil samples were immediately transferred to sterile bags, placed in a cooled and insulated container, transferred to the laboratory and stored at $4{ }^{\circ} \mathrm{C}$. Soil samples used for physico-chemical analyses were airdried and passed through a 2-mm sieve. In total, 225 samples were analyzed in this study ( 5 altitude levels $\times 3$ plots $\times 3$ subplots $\times 5$ profiles). The soils and forest floors collected from five elevation level were mixed and the mean of the humus layers and percentage of humus form were used to compute humus layer thickness and humus form classification, respectively.

Laboratory analysis of forest floor and soil physico-chemical and biological properties

Forest floor carbon (FFC) and nitrogen (FFN) contents were determined through dry combustion and semi micro-Kjeldahl techniques, respectively (Bremner \& Mulvaney 1982). Soil texture was determined using the Bouyoucos hydrometer method (Bouyoucos 1962). Soil moisture (SM) was measured after drying the soil samples in an oven at $105^{\circ} \mathrm{C}$ for $24 \mathrm{~h}$. Soil pH was measured in a ratio of 1:2.5 (M/V) of soil/water using an Orion ${ }^{\mathrm{TM}}$ Analyzer Model $901 \mathrm{pH}$

Tab. 2 - Correlation of vegetation, humus forms and soil features with PCA components. $\left(^{*}\right): p<0.05 ;(* *): p<0.01$.

\begin{tabular}{|c|c|c|c|c|c|}
\hline Features & PC1 & PC2 & Features & PC1 & PC2 \\
\hline Tree density & $-0.56 * *$ & 0.25 & Eumacroamphi & -0.33 & -0.20 \\
\hline Tree basal area & $0.39 *$ & -0.40 & Eumesoamphi & $-0.35^{*}$ & -0.37 * \\
\hline Tree crown density & $0.60 * *$ & $-0.67^{* *}$ & Pachyamphi & $-0.38 *$ & -0.25 \\
\hline Mean tree height & $0.34^{*}$ & $-0.76^{* *}$ & FFC & -0.32 & $-0.50^{* *}$ \\
\hline $\mathrm{OL}$ & $-0.65^{* *}$ & $-0.63 * *$ & FFN & 0.16 & 0.07 \\
\hline OF & $-0.75^{* *}$ & -0.32 & $\mathrm{FFC} / \mathrm{N}$ & -0.24 & -0.23 \\
\hline $\mathrm{OH}$ & $-0.67^{* *}$ & $-0.50 * *$ & SM & $-0.35^{*}$ & -0.26 \\
\hline $\mathrm{AH}$ & $0.57^{* *}$ & $-0.43 *$ & ST & $0.89 * *$ & -0.25 \\
\hline Eumull & 0.33 & 0.04 & $\mathrm{pH}$ & 0.23 & $-0.61^{* *}$ \\
\hline Mesomull & 0.25 & 0.03 & $\mathrm{CaCO}_{3}$ & 0.20 & -0.32 \\
\hline Oligomull & $0.54^{* *}$ & -0.09 & SOC & $-0.42 *$ & $-0.75^{* *}$ \\
\hline Rhizo Mesomull & -0.12 & 0.25 & SN & 0.24 & $-0.55^{* *}$ \\
\hline Rhizo Oligomull & -0.24 & $0.54^{* *}$ & $\mathrm{SC} / \mathrm{N}$ & $-0.63^{* *}$ & -0.23 \\
\hline Rhizo Dysmull & -0.24 & $0.54^{* *}$ & $M B C$ & -0.004 & $-0.47^{* *}$ \\
\hline Leptoamphi & -0.04 & -0.22 & MBN & $0.70 * *$ & -0.02 \\
\hline
\end{tabular}

meter (ThermoFischer Scientific, Waltham, MS, USA). Calcium carbonate $\left(\mathrm{CaCO}_{3}\right)$ content was determined by the neutralization titration method. Soil organic carbon (SOC) and soil nitrogen (SN) contents were determined based on the modified WalkleyBlack (Allison 1965) and semi Micro-Kjeldahl methods (Bremner \& Mulvaney 1982), respectively. The microbial biomass carbon (MBC) and microbial biomass nitrogen (MBN) were assessed through the fumigation-extraction method with a conversion factor of 0.45 for microbial $C$ and 0.54 for microbial N (Brookes et al. 1985, Sparling et al. 1998).

\section{Statistical analysis}

The normality of data was checked by the Kolmogorov Smirnov test $(P>0.05)$, and the homogeneity of variances was tested using the Levene's test $(P>0.05)$. One-way analysis of variance (ANOVA) was performed to analyze differences in vegetation properties, humus layer thickness (HLT), forest floor, soil physical, chemical and biological properties along the altitudinal gradient. Means were compared using Tukey HSD post-hoc test. Abundance of humus systems and forms in relation to the altitudinal gradient was tested by Fisher's exact test. Pearson's correlation analyses were performed to correlate the vegetation variables and forest floor and soil characteristics across the altitudinal gradient. For non-normally distributed data, the Spearman's correlation analysis was performed. All statistical analyses were conducted using SPSS ${ }^{\circledast}$ v. 16 (IBM Corp., Armonk, NY, USA). Multivariate correlations were analyzed using factor analysis based on principal components analyses (PCA) performed by the software PC-Ord V. 5.0 (McCune \& Mefford 1999).

\section{Results}

PCA revealed significant changes in all studied soil and humus characteristics along the altitudinal gradient (Tab. 2, Fig. $1 A-B)$, with greater than 45 percent of variations being explained. The left side of the
Fig. 1 - Principle component analysis (PCA) based on the correlation matrix to identify the relationships between forest types, humus forms, forest floor and soil properties (A-B). (PMF): plain mixed forests; (LMMF): low mountainous mixed forests; (MMMF): middle mountainous mixed forests; (HMPF): high mountainous pure forests; (F-GE): forestgrassland ecotone.
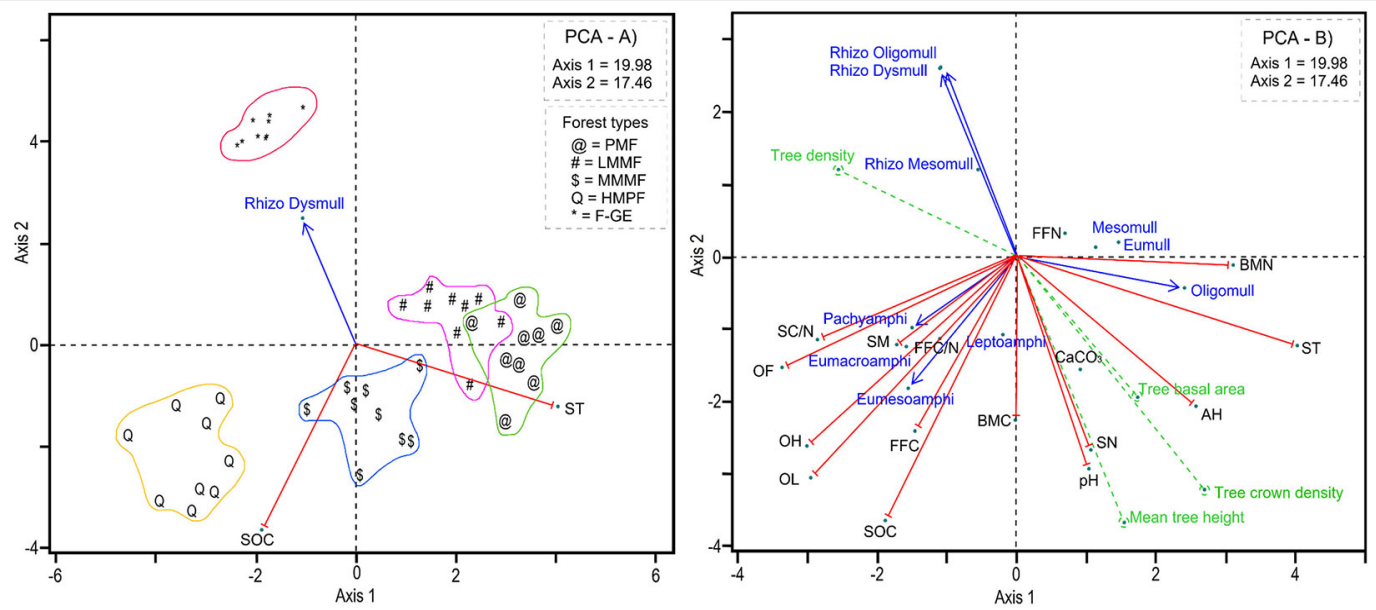
Fig. 2 - Abundance of humus systems $(A)$ and forms (B) in relation to altitudinal gradients $(n=45)$.
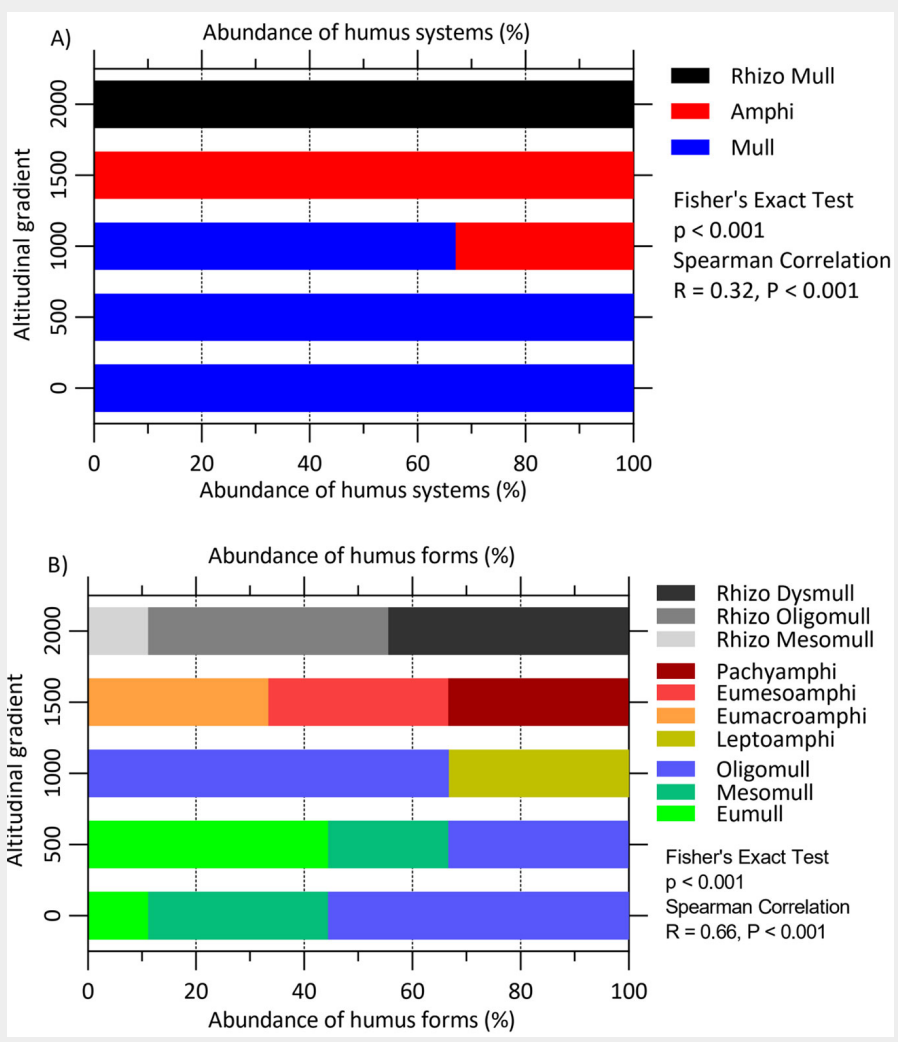

PC axis 1 reflects low quality of forest floor (i.e., high $\mathrm{FFC}, \mathrm{FFC} / \mathrm{N}$ and thickness), and soil (i.e., higher values of $S O C$ and $C / N$ ) which resulted in the formation of Amphi humus forms under high mountainous pure forests (Fig. 1B). The right side of PC axis 1 , instead, corresponds to conditions with higher forest productivity (tree basal area, tree crown density and mean tree

height), improved forest floor (i.e., N) and soil characteristics ( $\mathrm{N}$ content, $\mathrm{MBN}, \mathrm{pH}$ and $\left.\mathrm{CaCO}_{3}\right)$. In these conditions, the frequency of the mull humus forms was higher (plain mixed and low mountainous mixed forests - Fig. 1B). Middle mountainous mixed forests showed intermediate conditions with regard to the forest floor and soil properties and thus a strong rela-

Tab. 3 - One-way analysis of variance (ANOVA) and Pearson's correlation coefficients $\left(R_{\text {cor }}\right)$ of forest floor and soil characteristics along the altitudinal gradients. $\left(^{*}\right): p<$ $0.05 ;(* *): p<0.01$.

\begin{tabular}{|c|c|c|c|c|c|}
\hline $\begin{array}{l}\text { Humus and } \\
\text { soil properties }\end{array}$ & Variables & Abbr. & $F$ test & $P$ value & $\mathbf{R}_{\text {cor }}$ \\
\hline \multirow{4}{*}{$\begin{array}{l}\text { Humus layers } \\
\text { thickness }\end{array}$} & Organic litter (cm) & $\mathrm{OL}$ & 81.86 & $<0.001$ & $0.36^{*}$ \\
\hline & Organic fragmentation $(\mathrm{cm})$ & OF & 21.73 & $<0.001$ & $0.53^{* *}$ \\
\hline & Organic humus (cm) & $\mathrm{OH}$ & 40.81 & $<0.001$ & $0.36^{*}$ \\
\hline & Organic-mineral layer $(\mathrm{cm})$ & $\mathrm{AH}$ & 11.32 & $<0.001$ & $-0.62^{* *}$ \\
\hline \multirow{3}{*}{$\begin{array}{l}\text { Forest floor } \\
\text { properties }\end{array}$} & Forest floor carbon (\%) & FFC & 3.74 & 0.012 & 0.093 \\
\hline & Forest floor nitrogen (\%) & FFN & 15.84 & $<0.001$ & -0.09 \\
\hline & Forest floor $\mathrm{C} / \mathrm{N}$ & $\mathrm{FFC} / \mathrm{N}$ & 5.80 & $<0.001$ & 0.11 \\
\hline \multirow{2}{*}{$\begin{array}{l}\text { Soil physical } \\
\text { properties }\end{array}$} & Soil moisture (\%) & $S M$ & 3.24 & 0.021 & 0.25 \\
\hline & Soil temperature $\left({ }^{\circ} \mathrm{C}\right)$ & ST & 219.97 & $<0.001$ & $-0.94^{* *}$ \\
\hline \multirow{5}{*}{$\begin{array}{l}\text { Soil chemical } \\
\text { properties }\end{array}$} & Soil pH & $\mathrm{pH}$ & 75.08 & $<0.001$ & $-0.51^{* *}$ \\
\hline & Calcium carbonate (\%) & $\mathrm{CaCO}_{3}$ & 16.04 & $<0.001$ & $-0.45^{*}$ \\
\hline & Soil organic carbon $(\%)$ & SOC & 30.25 & $<0.001$ & 0.18 \\
\hline & Soil nitrogen (\%) & SN & 11.11 & $<0.001$ & $-0.39^{* *}$ \\
\hline & Soil C/N & $\mathrm{SC} / \mathrm{N}$ & 19.14 & $<0.001$ & $0.53^{* *}$ \\
\hline \multirow{2}{*}{$\begin{array}{l}\text { Soil biological } \\
\text { properties }\end{array}$} & $\begin{array}{l}\text { Microbial biomass carbon } \\
\left(\mathrm{mg} \mathrm{kg}^{-1}\right)\end{array}$ & $M B C$ & 24.22 & $<0.001$ & -0.007 \\
\hline & $\begin{array}{l}\text { Microbial biomass nitrogen } \\
\left(\mathrm{mg} \mathrm{kg}^{-1}\right)\end{array}$ & MBN & 44.08 & $<0.001$ & $-0.70^{* *}$ \\
\hline
\end{tabular}

tionship with leptoamphi humus and MBC (Fig. 1B). In addition, the forest-grassland ecotone with Rhizo-Mull humus forms did not show any relationship with soil properties (Fig. 1B).

As expected, canopy composition, stand features, humus forms and their characteristics changed with altitude (Tab. 1, Tab. 2). In the plain forest, ironwood was the dominant species followed by oak and hornbeam. However, ironwood density decreased with altitude and this species was totally absent at altitudes above $1500 \mathrm{~m}$ a.s.l. At intermediate altitudes (500 and $1000 \mathrm{~m}$ ), beech, ash and maple were the dominant species, while at higher altitude $(1500 \mathrm{~m})$ only beech was present. Above $2000 \mathrm{~m}$ a.s.l., hawthorn was the most common species. Total tree density significantly increased with altitude $(R=0.54, p<0.01)$, while basal area $(R=-0.39, p<0.01)$, crown density $(R=-0.79, p<0.01)$ and mean tree height $(R=-0.52, p<0.01)$ decreased.

Altitudinal gradient significantly affected the abundance of the humus systems $(p<$ $0.001)$ and humus forms ( $p<0.001-$ Fig. $2 \mathrm{~A})$. Mull was the dominant system below $1000 \mathrm{~m}$ a.s.l.; Amphi appeared at $1000 \mathrm{~m}$ and dominated at $1500 \mathrm{~m}$; Rhizo Mull was dominant under F-GE at $2000 \mathrm{~m}$ a.s.l. Oligomull was the most common form at 0 and $1000 \mathrm{~m}$ and Eumull at $500 \mathrm{~m}$ (Fig. 2B). At higher altitudes, no dominant humus form was detected. In fact, Eumacro, Eumeso and Pachyamphi humus forms were equally represented at $1500 \mathrm{~m}$, while at $2000 \mathrm{~m}$ Rhizo Mesomull, Rhizo Oligomull and Rhizo Dysmull were equally abundant (Fig. 2B).

The thickness of the organic layers including $\mathrm{OL}, \mathrm{OF}, \mathrm{OH}$ significantly increased with altitude $(R=0.36, p<0.05 ; R=0.53, p<$ $0.01 ; R=0.36, p<0.05$; respectively), whereas the organic-mineral thickness $(\mathrm{AH})$ decreased $(\mathrm{R}=-0.62, \mathrm{p}<0.01-$ Tab. 3 , Fig. 3). The thickness of $O L$ and $O F$ at 1500 $\mathrm{m}$ was approximately 2.5 times greater than that at the other altitudes $(p<0.001)$; the highest thickness of $\mathrm{OH}$ was recorded at $1500 \mathrm{~m}$ a.s.l., while this layer was not observed at 0, 500 and $2000 \mathrm{~m}$ altitudes (Tab. 3, Fig. 3).

No clear relationship was observed between forest floor properties (C, N and C/N ratio) and altitude (Tab. 3), though some significant differences among forest types were detected (Fig. 4). The highest value of forest floor $C$ was found in high mountainous pure forests (Fig. 4A), while the forest floor $\mathrm{N}$ was significantly higher at the plain mixed forests (Fig. 4B). The plain mixed forests, however, showed the lowest forest floor $\mathrm{C} / \mathrm{N}$ ratio (Fig. $4 \mathrm{C}$ ), while low and high mountainous mixed forests showed the highest forest floor $\mathrm{C} / \mathrm{N}$ ratio (Fig. 4C).

Soil properties, however, significantly changed with altitude (Tab. 3, Fig. 5). Soil temperature differed among forest types and decreased with altitude $(R=-0.94, p<$ $0.01)$. The lowest soil moisture was measured in plain mixed forests, while the high- 
est was recorded in high mountainous pure forests (Fig. 5A, Tab. 3). On the contrary, soil $\mathrm{pH}(\mathrm{R}=-0.51, \mathrm{p}<0.01)$, calcium carbonate $(R=-0.45, p<0.01)$, soil $N(R=-0.39, p$ $<0.01)$ and microbial biomass nitrogen $(R=$ $-0.70, p<0.01)$ decreased with altitude, while soil $\mathrm{C} / \mathrm{N}$ ratio increased $(\mathrm{R}=0.53, \mathrm{p}<$ 0.01). The highest soil $\mathrm{pH}$ and $\mathrm{CaCO}_{3}$ concentration were observed in plain mixed forests and high mountainous pure forests and the lowest in forest-grassland ecotone (Fig. 5B). The highest concentrations of soil $\mathrm{C}, \mathrm{C} / \mathrm{N}$ ratios and $\mathrm{BMC}$ values were measured under high and middle mountainous forests, whereas plain mixed forests showed the highest soil $\mathrm{N}$ concentrations and $B M N$ values (Fig. 6).

\section{Discussion}

We showed that there exist significant associations between altitudinal gradient and forest characteristics including tree composition, stem density, tree height in Hyrcanian forest in northern Iran, consistently with findings of other studies previously

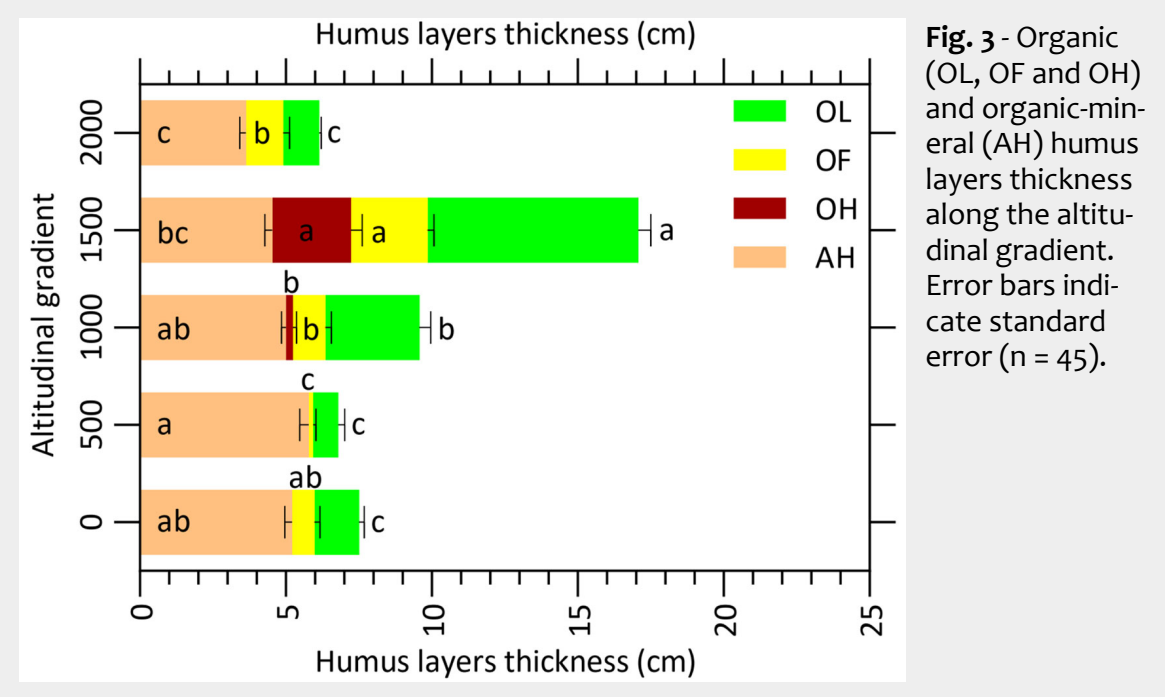

published (Naqinezhad et al. 2013, Bayranvand et al. 2018). The distribution of humus forms also changed with altitudinal gradicreased with altitude, while Amphi forms increased. With respect to the forest type, our results showed that Oligomull and Lepent. Particularly, Mull humus forms de- toamphi were dominant in mixed beech
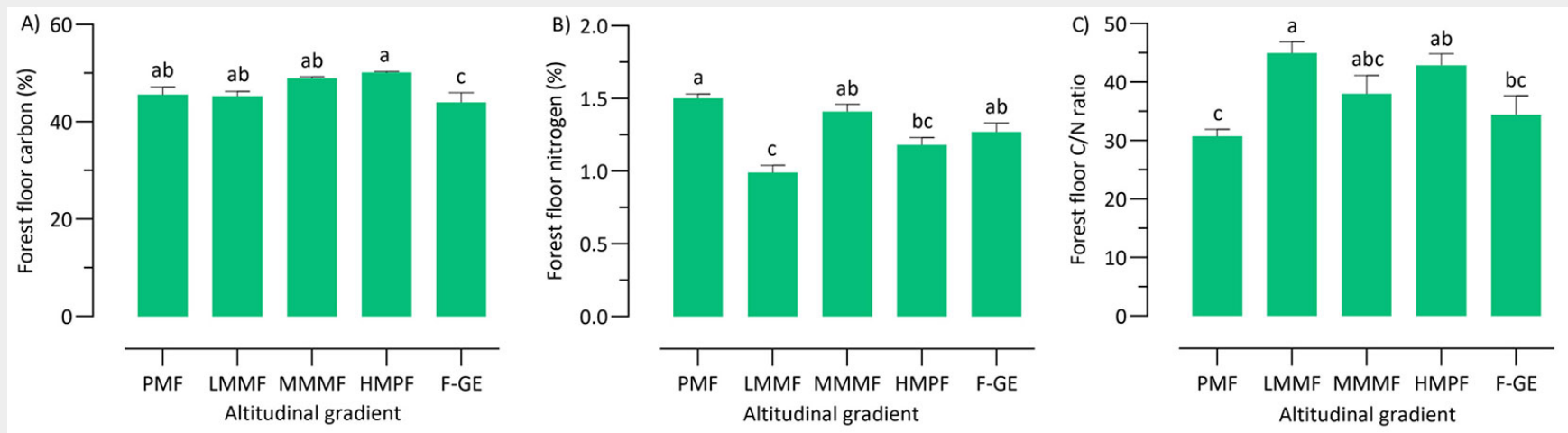

Fig. 4 - Mean floor carbon (A), nitrogen (B), and C/N ratio (C) among the altitude levels. Different letters indicate significant differences $(p<0.05)$ according to the ANOVA and Tukey HSD test. Error bars indicate standard error $(n=9)$. (PMF): plain mixed forests; (LMMF): low mountainous mixed forests; (MMMF): middle mountainous mixed forests; (HMPF): high mountainous pure forests; (F-GE): forest-grassland ecotone.

Fig. 5 - Mean soil moisture and soil temperature (A), $\mathrm{pH}$ and $\mathrm{CaCO}_{3}$ (B) among the altitudes. Different letters indicate significant differences ( $p$ $<0.05$ ) based on ANOVA and Tukey HSD test.

Error bars indicate standard error $(n=9)$. (PMF): plain mixed forests;

(LMMF): low mountainous mixed forests;

(MMMF): middle mountainous mixed forests; (HMPF): high mountainous pure forests; (F-GE): forest-grassland ecotone.
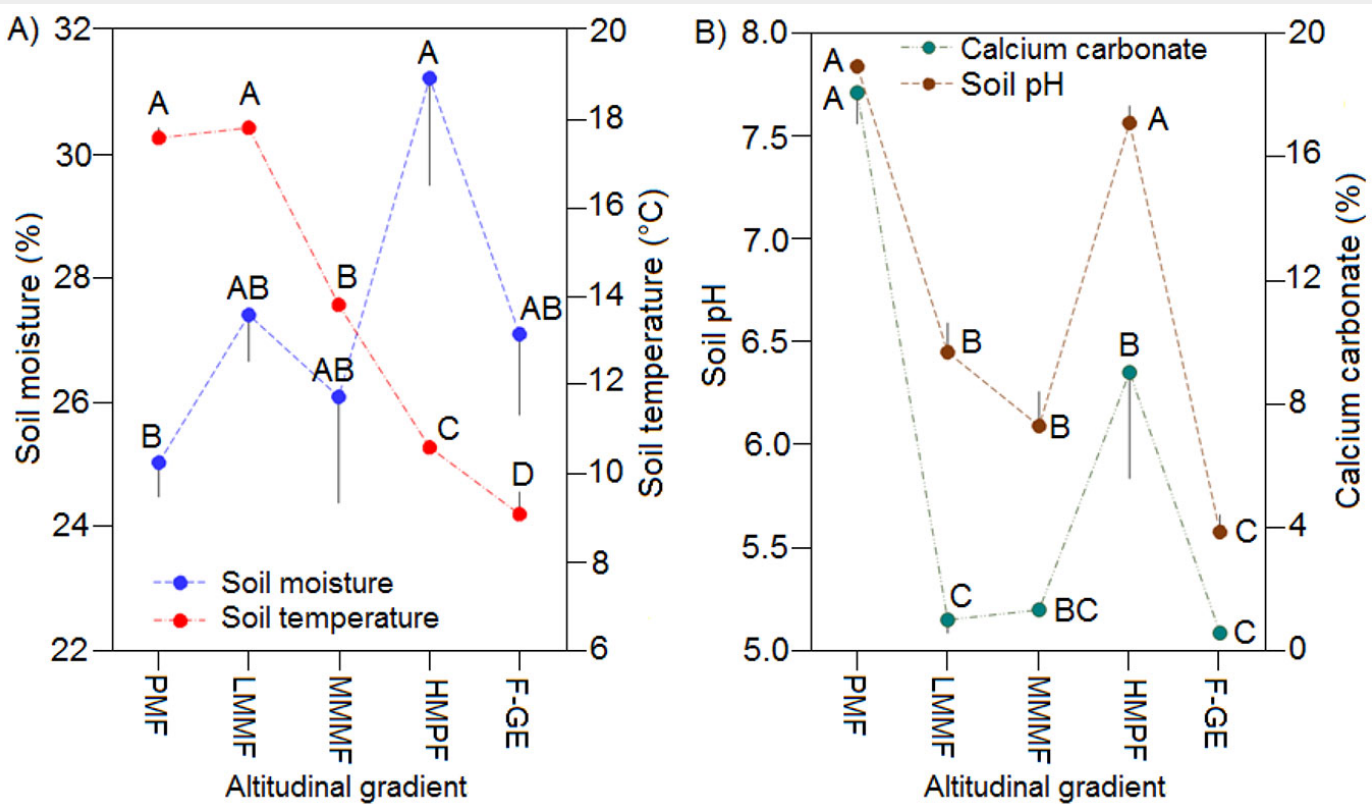


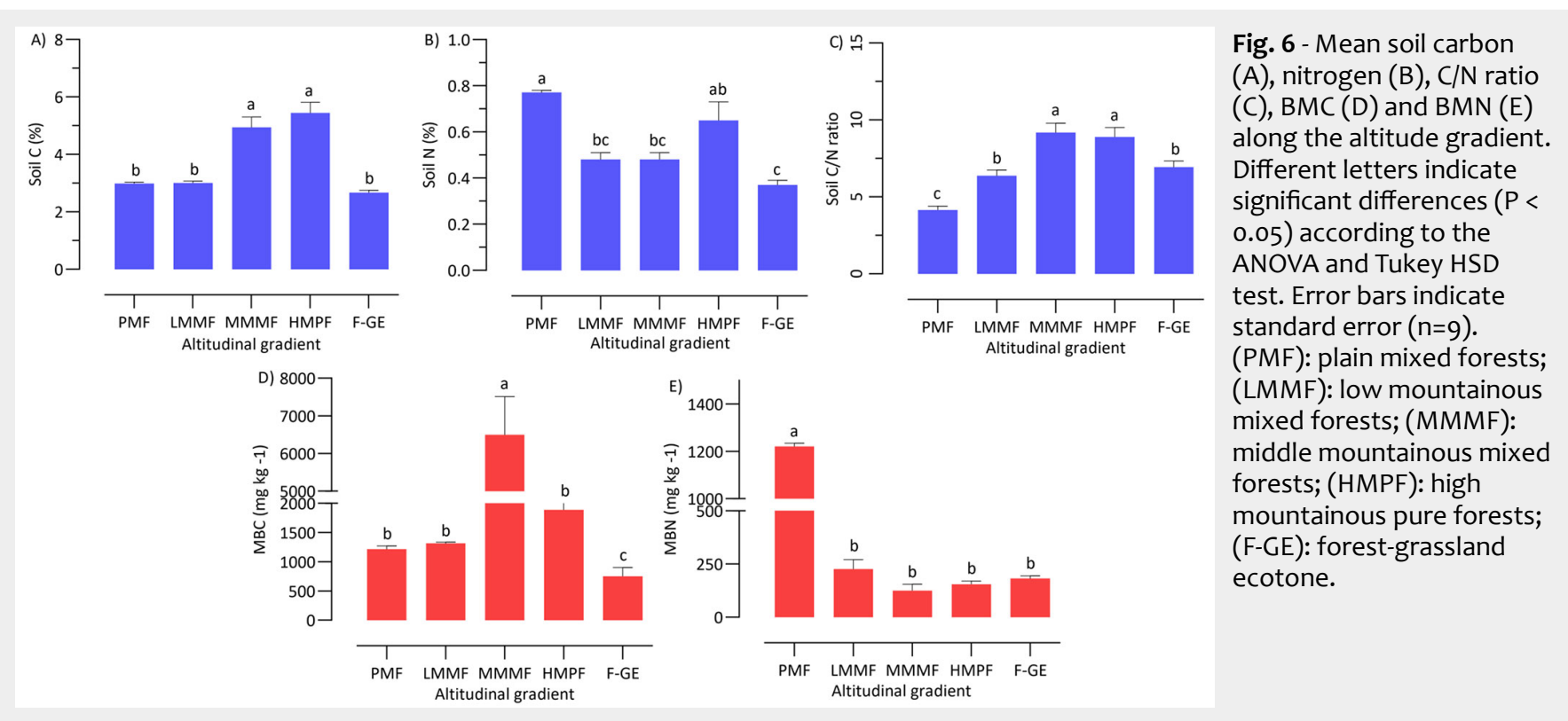

forests, while in pure beech forests Eumacroamphi, Eumesoamphi and Pachyamphi were the dominant forms. Previous study by Waez-Mousavi (2018) also reported that Mull and Amphi are the most dominant humus systems in the Hyrcanian forests. In mixed beech stands, Waez-Mousavi \& Habashi (2012) reported the dominance of Mull and Amphi humus systems.

Both environmental conditions and tree species composition influence humus formation and its characteristics. A significant change in soil temperature, moisture and species composition was noted in our altitudinal gradient. Previous study revealed that a decrease in mean temperature associates with a decline in Mull humus form and an increase in Amphi humus (Ponge et al. 2011). In agreement to our finding in plain mixed forest, Ponge et al. (2011) noted that Mull systems are more frequent at higher tree species diversity and under rich trophic conditions. In contrary, under low tree species richness and in colder environments, Moder and Amphi humus systems with $\mathrm{OF}$ and $\mathrm{OH}$ layers are dominant (Badía-Villas \& Girona-García 2018). Labaz et al. (2014) showed that Amphi humus forms can be found in cold conditions where organic matter decomposition is slower. Previous study by Waez-Mousavi \& Habashi (2012) indicated that Mull humus forms are abundant under forest types with higher floor quality and decomposition rate, while Amphi and Moder humus forms are observed under beech forest type with low floor quality (high $\mathrm{C}$ and low $\mathrm{N}$ - Bayranvand et al. 2017a). Mull humus forms are biologically active (Endogeic and Anecic with high activity) with fine-granular structure, which have low SOC content compared to humus forms with $\mathrm{OF}$ and $\mathrm{OH}$ layers (Jabiol et al. 2013, Labaz et al. 2014). Moder forms are abundant in beech dominated forest with low soil $\mathrm{pH}(\approx 5.5)$, while Mull forms are absent in non-beech stands (Bayranvand et al. 2018). The increased
Amphi humus form under pure beech forest $(1500 \mathrm{~m})$ could likely be due to high soil $\mathrm{pH}(>7.5)$ resulted from high $\mathrm{CaCO}_{3}$ concentrations ( $\mathrm{Li}$ et al. 2018). The $\mathrm{CaCO}_{3}$ concentration has probably a positive impact on the forest floor decomposition rate and soil microbial activity (Guo et al. 2019) and could likely facilitate the transition from Moder to Amphi form (Labaz et al. 2014, Bonifacio et al. 2018).

Previous studies showed that climatic (moisture and temperature) and biotic factors (species type and richness) are important factors influencing humus accumulation (Zanella et al. 2011, Labaz et al. 2014, Badía-Villas \& Girona-García 2018). In our study, the thickness of OL, OF, OH layers significantly were increased, while that of $\mathrm{AH}$ was decreased. The more favorable conditions for organic matter decomposition in plain mixed forests (i.e., high temperature, good soil moisture and high litter quality) is likely the cause (Salmon 2018). Similarly, Bonifacio et al. (2018) also showed that the $\mathrm{OH}$ layer thickness in beech forests with a low litter quality is higher than in hornbeam, maple and ash forests (Labaz et al. 2014). Thus, the higher $\mathrm{OH}$ layer thickness at $1500 \mathrm{~m}$ a.s.l. found in this study can be attributed to the low temperature in this elevation level, which slow down mineralization rates (Badía-Villas \& Girona-García 2018), decrease litter quality under beech (Bayranvand et al. 2017a) and higher soil moisture (Zanella et al. 2011).

The chemical composition of humus and soil are the result of the interaction of many factors including topography, climate, tree cover and soil microbial communities (Ponge et al. 2011). Shedayi et al. (2016) showed that altitude has a low impact on soil organic carbon and nitrogen, while vegetation cover explains most of the measured variations. Bayranvand et al. (2017a) reported that, although tree species affect soil chemical properties (i.e., $\mathrm{pH}$,
$\mathrm{C}$, and $\mathrm{N}$ content), earthworm and microbial activity were mostly controlled by climate. Our results support the idea that soil properties including temperature, $\mathrm{pH}$, $\mathrm{CaCO}_{3}$, soil $\mathrm{N}$ content, soil $\mathrm{C} / \mathrm{N}$ and microbial biomass $\mathrm{N}$ are significantly correlated with altitude, while most forest floor properties are not directly influenced by temperature, but affected by tree species composition. In fact, litter quality influences both decomposition rates and the dynamic of nutrient mineralization (Lucas-Borja et al. 2019). Previous studies have argued that higher forest floor $\mathrm{N}$ concentrations are associated with faster litter decomposition rates (Kooch \& Bayranvand 2017, LucasBorja et al. 2019). A decrease in forest floor quality (high $\mathrm{C}$ content and high $\mathrm{C} / \mathrm{N}$ ratio) was reported to associate with a higher humus layer thickness and a decreased decomposition rate in beech dominated forests at high altitudes (Bayranvand et al. 2017b). In fact, beech litter is known for having a high lignin/ $\mathrm{N}$ ratio and a relatively low contents of basic cations and N (Bonifacio et al. 2018). In agreement with our findings, low humus layer thickness is related to high quality floors in maple, ironwood, alder and hornbeam (Kooch \& Bayranvand 2017, Bayranvand et al. 2017b). Forest floor $\mathrm{C} / \mathrm{N}$ ratio and $\mathrm{N}$ content are the two most important factors influencing litter decomposition and nutrient release (Lucas-Borja et al. 2019).

Badía-Villas \& Girona-García (2018) reported that forest floor $\mathrm{N}$ in mountain forest in Spain is decreased during shift from Mull to Amphi forms with increasing elevation. Ponge et al. (2011) measured lower $C$ content in Mull than in other humus forms. It could be speculated that Mull forms decompose faster and introduce more $\mathrm{N}$ into the soil. Zanella et al. (2011) argued that forest floor and soil $\mathrm{C} / \mathrm{N}$ ratios in Mull are usually lower than in Amphi and the $\mathrm{C} / \mathrm{N}$ is an important indicator for the decomposition rate and nutrient cycling in the humus 
and soil

Our data also showed a significant decrease in soil MBN under different canopy compositions along the elevation gradient. $M B N$ was significantly higher in mixed forest types (i.e., PMF) at the lowest elevation than in pure stands at the highest elevation levels (i.e., HMPF). This may be the result of a greater and a more diverse litter input in stands with a higher species richness or diversity (Wang \& Wang 2011). Many investigations have also documented that soil microbial community structure is primarily driven by soil $\mathrm{pH}$ and $\mathrm{C} / \mathrm{N}$ ratio as the altitude increases. Thus, higher levels of $\mathrm{pH}$, such as those at low elevations, may be related to increased microbial biomass and bacterial diversity ( $\mathrm{Xu}$ et al. 2015). Higher levels of soil temperature and $\mathrm{N}$ content, such as those at low elevations, may contribute to a larger microbial biomass (Xu et al. 2015, Bojko \& Kabala 2017, Guo et al. 2019).

Beech litter quality, FFC accumulation and lower earthworm activity are main factors affecting soil quality in this forest system. PMF was correlated with Mull humus and higher forest floor and soil quality (high FFN and SN; low FFC and SN). In this condition, tree species composition along with high biological and microbial activities (i.e., high temperature and soil water content) speed up organic matter decomposition (Zaiets \& Poch 2016). Mull humus forms are nutrient rich systems with fast nutrient cycling (Andreatta et al. 2011) which are associated to high earthworm activity and microbial biomass. In hornbeam and maple trees (MMMF) forest systems, higher forest floor quality and improved soil fertility support larger biological activities than in pure beech forests (Kooch \& Bayranvand 2017).

\section{Conclusion}

Altitudinal gradient is a key factor determining the distribution of humus forms. Soil properties (temperature, $\mathrm{pH}, \mathrm{CaCO}_{3}, \mathrm{~N}$ content, $\mathrm{C} / \mathrm{N}$ and $\mathrm{MBN}$ ) were significantly correlated with altitude, while forest floor properties were more influenced by tree species composition. Our data suggest that the abundance of Mull forms decrease from plain mixed forests to high mountain pure forests, whereas the frequency of Amphi humus forms increase. On the other hand, Oligomull and Leptoamphi are more abundant in mixed beech forests, while Eumacroamphi, Eumesoamphi and Pachyamphi are observed only in pure beech forests. In addition, plain mixed forests typically have higher quality of both forest floor (i.e., $\mathrm{N}$ ) and soil (i.e., $\mathrm{pH}, \mathrm{CaCO}_{3}$, soil $\mathrm{N}$ content, soil $\mathrm{C} / \mathrm{N}$ and $\mathrm{MBN}$ ) than high mountainous pure one, while middle mixed forests show intermediate characteristics.

\section{Abbreviations}

OL: Organic litter; OF: Organic fragmentation; OH: Organic humus; AH: Organic-mineral layer; FFC: Forest floor carbon; FFN:
Forest floor nitrogen; FFC/N: Forest floor C/ $\mathrm{N}$; SM: Soil moisture; ST: Soil temperature; $\mathrm{pH}$ : Soil $\mathrm{pH} ; \mathrm{CaCO}_{3}$ : Calcium carbonate; SOC: Soil organic carbon; SN: Soil nitrogen; $\mathrm{SC} / \mathrm{N}$ : Soil C/N; MBC: Microbial biomass carbon; MBN: Microbial biomass nitrogen.

\section{Author contributions}

$M B$ and $M A$ conceived and designed the experiment. $M B$ performed the experiment. MB, GA and GS-J carried out the statistical analysis. MB, JG, GA and GS-J contributed to the data analysis and data interpretation. MB, JG, GS-J and GA wrote and edited the manuscript.

\section{Acknowledgements}

This research was funded by a grant provided by Tarbiat Modares University (TMU) and Iran National Science Foundation (INSF). We would like to thank Mr. J. Eslamdoust, A. Khodadust, MR Soleimani, E. Sharifi, M. Mohammadi, and A. Daryaei for their assistance during field samplings. We also thank M. Naeiji and M. Haghdoust for their assistance during laboratory analysis of the soil samples. The authors also express their sincere appreciation to Augusto Zanella for helping with morphological identification of humus forms and Björn Berg for reviewing the manuscript.

\section{References}

Allison LE (1965). Organic carbon. In: "Methods of Soil Analysis American Society of Agronomy. Part 2" (Black CA ed). American Society of Agronomy, Soil Science Society of America, Madison, WI, USA, pp. 1367-1378. - doi: 10.2134/ agronmonogr9.2.c39

Andreatta A, Ciampalini R, Moretti P, Vingiani S, Poggio G, Matteucci G, Tescari F, Carnicelli S (2011). Forest humus forms as potential indicators of soil carbon storage in Mediterranean environments. Biology and Fertility of Soils 47: 31-40. - doi: 10.1007/s00374-010-0499-z

Ascher J, Sartori G, Graefe U, Thornton B, Ceccherini MT, Pietramellara G, Egli M (2012). Are humus forms, mesofauna and microflora in subalpine forest soils sensitive to thermal conditions?. Biology and Fertility of Soils 48: 709725. - doi: 10.1007/s00374-012-0670-9

Badía-Villas D, Girona-García A (2018). Soil humus changes with elevation in Scots pine stands of the Moncayo Massif (NE Spain). Applied Soil Ecology 123: 617-621. - doi: 10.1016/j.apsoil.2017. 07.017

Bayranvand M, Kooch Y, Alberti G (2018). Classification of humus forms in Caspian Hyrcanian mixed forests ecoregion (Iran): comparison between two classification methods. Catena 165: 390-397. - doi: 10.1016/j.catena.2018.02.021 Bayranvand M, Kooch Y, Rey A (2017a). Earthworm population and microbial activity temporal dynamics in a Caspian Hyrcanian mixed forest. European Journal of Forest Research 136: 447-456. - doi: 10.1007/s10342-017-1044-5

Bayranvand M, Kooch $\mathrm{Y}$, Hosseini SM, Alberti G (2017b). Humus forms in relation to altitude and forest type in the Northern mountainous regions of Iran. Forest Ecology and Management 385: 78-86. - doi: 10.1016/j.foreco.2016.11.
035

Bohlen PJ (2002). Earthworms. Oligochaeta: Archipheretima, Metapheretima, Planapheretima, Pleinogaster and Polypheretima. Encyclopedia of Soil Science, Bulletin of the British Museum Natural History, Archbold Biological Station, Venus, FL, USA, pp. 1-128.

Bojko O, Kabala C (2017). Organic carbon pools in mountain soils - Sources of variability and predicted changes in relation to climate and land use changes. Catena 149: 209-220. - doi: 10.1016/j.catena.2016.09.022

Bonifacio E, D'Amico M, Catoni M, Stanchi S (2018). Humus forms as a synthetic parameter for ecological investigations. Some examples in the Ligurian Alps (North-Western Italy). Applied Soil Ecology 123: 568-571. - doi: 10.1016/j.apsoil. 2017.04.008

Bouyoucos GJ (1962). Hydrometer method improved for making particle size analysis of soils. Agronomy Journal 56: 464-465. - doi: 10.2134/ag ronj1962.00021962005400050028x

Bremner JM, Mulvaney CS (1982). Nitrogen-total. In: "Methods of Soil Analysis, Part 2 ( $2^{\text {nd }}$ edn)" (Page AL, Miller RH, Keeney RR eds). American Society of Agronomy, Madison WI, USA, pp. 595-624.

Brookes PC, Landman A, Pruden G, Jenkinson DS (1985). Chloroform fumigation and the release of soil $\mathrm{N}$ : a rapid direct extraction method to measure microbial biomass nitrogen in soil. Soil Biology and Biochemistry 17: 837-842. - doi: 10.1016/0038-0717(85)90144-0

IUSS Working Group (2015). World reference base for soil resources 2014. International soil classification system. World Soil Resources Reports no. 106, Food and Agriculture Organization of the United Nations, Rome, Italy. - doi: 10.1017/So014479706394902

Guo A, Ding L, Tang Z, Zhao Z, Duan G (2019). Microbial response to $\mathrm{CaCO}_{3}$ application in an acid soil in southern China. Journal of Environmental Sciences 79: 321-329. - doi: 10.1016/j.jes.2018. 12.007

Jabiol B, Zanella A, Ponge JF, Sartori G, Englisch M, Van Delft B, De Waal R, Le Bayon RC (2013). A proposal for including humus forms in the World Reference Base for Soil Resources (WRBFAO). Geoderma 192: 286-294. - doi: 10.1016/j. geoderma.2012.08.002

Karger DN, Conrad O, Böhner J, Kawohl T, Kreft $\mathrm{H}$, Soria-Auza RW, Zimmermann NE, Linder HP, Kessler M (2017). Climatologist at high resolution for the Earth's land surface areas. Scientific Data 4: 170122

Khaleghi P, Abasi H, Hosani S, Frohar M, Ghelichnian H (1997). Caspian forests profile, Vaz Research Forest. Ministry of Jihad-e-Production, Department of Education and Research, Research Institute for Forests and Rangelands, Tehran, Iran, pp. 380.

Kooch Y, Bayranvand M (2017). Composition of tree species can mediate spatial variability of $C$ and $\mathrm{N}$ cycles in mixed beech forests. Forest Ecology and Management 401: 55-64. - doi: 10.1016/j.foreco.2017.07.001

Labaz B, Galka B, Bogacz A, Waroszewski J, Kabala $C$ (2014). Factors influencing humus forms and forest litter properties in the mid-mountains under temperate climate of southwestern Poland. Geoderma 230: 265-273. - doi: 10.1016/j. 
geoderma.2014.04.021

Li Z, Wei B, Wang X, Zhang Y, Zhang A (2018). Response of soil organic carbon fractions and $\mathrm{CO}_{2}$ emissions to exogenous composted manure and calcium carbonate. Journal of Soils and Sediments 18: 1832-1843. - doi: 10.1007/s11368018-1946-y

Lucas-Borja ME, De Santiago JH, Yang Y, Shen Y, Candel-Pérez D (2019). Nutrient, metal contents and microbiological properties of litter and soil along a tree age gradient in Mediterranean forest ecosystems. Science of the Tota Environment 650: 749-758. - doi: 10.1016/j.scito tenv.2018.09.079

McCune B, Mefford MJ (1999). PC-ORD for Windows: multivariate analysis of ecological data, version 4.01. MjM Software, Glenedon Beach, Oregon, USA.

Naqinezhad A, Zare-Maivan $\mathrm{H}$, Gholizadeh $\mathrm{H}$, Hodgson JG (2013). Understory vegetation as an indicator of soil characteristics in the Hyrcanian area, N. Iran. Flora 208: 3-12. - doi: 10.1016/j. flora.2012.12.002

Ponge JF (2013). Plant-soil feedbacks mediated by humus forms: a review. Soil Biology and Biochemistry 57: 1048-1060. - doi: 10.1016/j.soilbio. 2012.07.019

Ponge JF, Jabiol B, Gégout JC (2011). Geology and climate conditions affect more humus forms than forest canopies at large scale in temperate forests. Geoderma 162: 187-195. doi: 10.1016/j.geoderma.2011.02.003

Salmon S (2018). Changes in humus forms, soil invertebrate communities and soil functioning with forest dynamics. Applied Soil Ecology 123: 345-354. - doi: 10.1016/j.apsoil.2017.04.010

Shedayi AA, Xu M, Naseer I, Khan B (2016). Altitudinal gradients of soil and vegetation carbon and nitrogen in a high-altitude nature reserve of Karakoram ranges. SpringerPlus 5: 320-334. doi: 10.1186/s40064-016-1935-9

Sparling G, Vojvodić-Vuković M, Schipper LA
(1998). Hot-water-soluble $C$ as a simple measure of labile soil organic matter: the relationship with microbial biomass C. Soil Biology and Biochemistry 30: 1469-1472. - doi: 10.1016/So03 8-0717(98)00040-6

Waez-Mousavi SM (2018). Humus systems in the Caspian Hyrcanian temperate forests. Applied Soil Ecology 123: 664-667. - doi: 10.1016/j.apsoil. 2017.09.022

Waez-Mousavi SM, Habashi H (2012). Evaluating humus forms variation in an unmanaged mixed beech forest using two different classification methods. iForest - Biogeosciences and Forestry 5: 272-275. - doi: 10.3832/iforo632-005

Wang Q, Wang S (2011). Response of labile soil organic matter to changes in forest vegetation in subtropical regions. Applied Soil Ecology 47: 210-216. - doi: 10.1016/j.apsoil.2010.12.004

Xu Z, Yu G, Zhang X, Ge J, He N, Wang Q, Wang D (2015). The variations in soil microbial communities, enzyme activities and their relationships with soil organic matter decomposition along the northern slope of Changbai Mountain. Applied Soil Ecology 86: 19-29. - doi: 10.1016/j.ap soil.2014.09.015

Zaiets O, Poch RM (2016). Micromorphology of organic matter and humus in Mediterranean mountain soils. Geoderma 272: 83-92. - doi: 10.1016/j.geoderma.2016.03.006

Zanella A, Jabiol B, Ponge JF, Sartori G, De Waal R, Van Delft B, Graefe U, Cools N, Katzensteiner $K$, Hager H, Englisch M (2011). A European morpho-functional classification of humus forms. Geoderma 164: 138-14. - doi: 10.1016/j.geoderma .2011 .05 .016

Zanella A, Ponge JF, Jabiol B, Sartori G, Kolb E, Le Bayon RC, Gobat JM, Aubert M, De Waal R, Van Delft B, Vacca A (2018). Humusica 1, article 5: Terrestrial humus systems and forms-Keys of classification of humus systems and forms. Applied Soil Ecology 122: 75-86. - doi: 10.1016/j.ap soil.2017.06.012
Zhang B, Liang C, He H, Zhang X (2013). Variations in soil microbial communities and residues along an altitude gradient on the northern slope of Changbai Mountain, China. PLoS One 8: e66184. - doi: 10.1371/journal.pone.0066184

\section{Supplementary Material}

Fig. S1 - (a) The Central Caspian region of northern Iran; (b) the study site at the Experimental Forest Station (Vaz watershed).

Fig. S2 - Mean monthly air temperature $\left({ }^{\circ} \mathrm{C}\right)$ and precipitation $(\mathrm{mm})$ at the study site based on the Noushahr city metrological station report.

Fig. S3 - Two examples of humus profiles at the sea level (o $\mathrm{m}$ a.s.l. - PMF).

Fig. S4 - Two examples of humus profiles at the $500 \mathrm{~m}$ a.s.l. (LMMF).

Fig. S5 - Two examples of humus profiles at the $1000 \mathrm{~m}$ a.s.l. (MMMF).

Fig. $\mathbf{S 6}$ - One example of humus profile at the $1500 \mathrm{~m}$ a.s.l. (HMPF).

Fig. S7 - Two examples of humus profiles at the $2000 \mathrm{~m}$ a.s.l. (F-GE).

Tab. S1 - Humus systems (Mull, Rhizo Mull and Amphi), Humus forms (Eumell, Mesomull, Oligomull, Rhizo Mesomull, Rhizo Oligomull and Rhizo Dysmull; Leptoamphi, Eumacroamphi and Eumesoamphi and Pachyamphi) and their diagnosic horizons.

Link: Bayranvand_3444@supploo1.pdf 